\title{
PENGARUH STRATEGI BAURAN PEMASARAN TERHADAP KEPUTUSAN SISWA DALAM MEMILIH MADRASAH ALIYAH NEGERI TUBAN
}

\author{
Supriyani \\ Jurusan Manajemen Pendidikan, Fakultas Ilmu Pendidikan, Universitas Negeri Surabaya \\ E-mail: supriyani44@yahoo.com \\ Heryanto Susilo \\ Jurusan Pendidikan non formal, Fakultas Ilmu Pendidikan, Universitas Negeri Surabaya \\ Email: heri_pls@yahoo.co.id
}

\begin{abstract}
Abstrak
Penelitian ini bertujuan untuk mengetahui pengaruh bauran pemasaran yang terdiri dari produk, harga, lokasi, dan bukti fisik secara parsial terhadap keputusan siswa dalam memilih MAN Tuban, serta mengetahui pengaruh produk, harga, lokasi, dan buti fisik secara bersama-sama terhadap keputusan siswa memilih MAN Tuban. Metode penelitian yang digunakan adalah metode analisis linear berganda, dengan menggunakan uji simultan dan uji parsial. Sampel yang diambil sebanyak 81 siswa kelas X MAN Tuban dengan menggunakan teknik simple random sampling.

Hasil penelitian menunjukan bahwa produk, harga, lokasi, dan promosi secara bersama-sama berpengaruh terhadap keputusan siswa memilih MAN Tuban sebesar 48,6\%. Hasil uji secara parsial diperoleh bahwa produk dan harga tidak berpengaruh terhadap keputusan siswa memilih MAN Tuban, sedangkan lokasi memiliki nilai signifikan 0,001 $<0,05$ dan nilai t hitung sebesar 3.463 yang > 1,99. Selain itu variabel bukti fisik memberikan pengaruh dengan nilai signifikan $0,009<0,05$ dan nilai t hitung $2.690>1,99$. Hal ini menunjukan bahwa diantara produk, harga, lokasi, dan bukti fisik hanya variabel lokasi dan bukti fisik yang mempengaruhi keputusan siswa memilih MAN Tuban.
\end{abstract}

Kata kunci: produk, harga, lokasi, sarana fisik, keputusan memilih

\section{PENDAHULUAN}

Sektor jasa dewasa ini telah mengalami peningkatan yang signifikan. Hal tersebut terlihat dari kontribusinya terhadap sektor perekonomian dunia. Di Indonesia sendiri, kontribusi sektor jasa mencapai $30 \%$ terhadap perekonomian Indonesia. Kontribusi tersebut tak terkecuali pada sektor jasa pendidikan yang notabene merupakan sektor jasa non profit atau nirlaba. Pendidikan tergolong sektor jasa karena pendidikan berfokus pada peningkatan kompetensi siswa dan hasil dari sektor ini tidak berupa produk atau barang akan tetapi berupa pengetahuan dan keterampilan.

Saat ini masyarakat sudah mulai menyadari pentingnya pendidikan bagi hidupnya, hal tersebut yang menjadikan menurunnya anak putus sekolah dibandingkan dengan tahun-tahun sebelumnya. Semakin lama pun dunia usaha dan dunia industri dalam merekrut tenaga kerja juga membutuhkan kualifikasi khusus minimal saat ini adalah lulusan SMA. Menanggapi hal tersebut pemerintah pusat menyediakan program wajib belajar 12 tahun. Program tersebut dinamakan Program Menengah Universal (PMU) yang berisi anjuran bagi pemerintah daerah untuk menyelenggarakan wajar 12 tahun. Anjuran wajib belajar 12 tahun bagi daerah/ kota tersebut tentu akan menjadikan semakin banyak sekolah-sekolah baru yang berdiri khusunya sekolah menengah atas.

Sekolah yang baru berdiri tentu saja menawarkan inovasi yang beragam dan berbeda dengan sekolah yang sudah ada sebelumnya. Ditingkat menengah atas saat ini banyak berdiri sekolah berbasis keislaman dengan model Boarding School atau sekolah berasrama. Melihat fenomena masyarakat saat ini, dimana banyak orangtua yang sibuk bekerja dan tidak sempat mendidik anaknya secara mendalam menjadikan boarding school sebagai pilihan bagi orang tua untuk menyekolahkan anaknya. Boarding school sebagai alternatif orangtua karena di boarding school anak akan diajarkan bukan hanya mata pelajaran saja melainkan keagamaan dan kemandirian. 
Salah boarding school, Promosi SMK pun saat ini sudah digencarkan melalui berbagai media seperti televisi, surat kabar, dan banner dan lain-lain. Dengan promosi tersebut cukup membuka pikiran masyarakat terutama orangtua. Dimana mereka memilih anaknya masuk di SMK. Orangtua mempercayakan pendidikan di SMK, karena dengan SMK bakat dan minat anaknya dapat terasah dengan jurusan yang dipilih. Hal ini menunjukan bahwa persaingan antar lembaga pendidikan semakin tinggi. Sekolah-sekolah yang sudah berdiri lama harus bertambah kualitas baik dari kurikulum, sitem pembelajaran, dan yang paling utama adalah startegi pemasaran lembaga.

Pemasaran memang terdengar aneh jika diterapkan pada sektor pendidikan karena pendidikan merupakan sektor nirlaba. Akan tetapi sekolah perlu melakukan pemasaran. Menurut Wijaya (2008:42), pemasaran dikatakan penting karena beragam pertimbangan. Pertama, sebagai lembaga nonprofit yang bergerak dalam jasa pendidikan, untuk level apa saja, kita perlu meyakinkan masyarakat dan pelanggan (peserta didik, orangtua, serta pihak-pihak terkait lainnya) bahwa lembaga pendidikan yang kita kelola masih tetap eksis. Kedua, kita perlu meyakinkan masyarakat dan pelanggan bahwa layanan jasa yang kita lakukan sungguh relevan dengan kebutuhan mereka. Ketiga, kita perlu melakukan kegiatan pemasaran agar jenis dan macam jasa pendidikan yang kita lakukan dapat dikenal dan dimengerti secara luas oleh masyarakat apalagi pelanggan, Keempat, agar eksistensi lembaga pendidikan yang kita kelola tidak ditinggalkan oleh masyarakat serta pelanggan potensial.

Salah satu strategi pemasaran yang bisa digunakan oleh sekolah yakni dengan strategi bauran pemasaran. Bauran pemasaran (marketing mix) menurut Lupiyoadi dan Hamdani (2006:70) merupakan alat bagi pemasar yang terdiri dari berbagai unsur suatu program pemasaran yang perlu dipertimbangkan agar implementasi strategi pemasaran yang ditetapkan berjalan dengan sukses. Unsur bauran pemasaran dalam bidang jasa meliputi 7P yaitu product (produk), Price (harga), promotion (promosi), place (tempat), People (SDM) atau tenaga pendidik dan kependidikan yang ada, Physical evidence (bukti fisik) atau sarana dan prasarana, dan process (proses) atau manajemen layanan pembelajaran yang diberikan. Dalam penelitian ini hanya terbatas pada empat unsur bauran pemasarn yakni produk, harga, lokasi, dan bukti fisik.

Produk menurut Kottler (1984:3) merupakan segala sesuatu yang dapat ditawarkan produsen untuk diperhatikan, diminta, dibeli, digunakan atau dikonsumsi pasar sebagai pemenuhan kebutuhan atau keinginan pasar yang bersangkutan. Kotler (1984:4) membagi produk menjadi tiga tingkat yakni a) produk inti, b) produk formal, dan c) produk yang disempurnakan. Pengertian produk di atas merupakan produk dalam bidang umum, sedangkan produk dalam jasa seperti yang diungkapkan Machali (2012:3) produk dalam konteks jasa pendidikan adalah jasa yang ditawarkan kepada pelanggan berupa reputasi, prospek dan variasi pilihan. Lembaga pendidikan yang mampu bertahan dan mampu memenangkan persaingan jasa pendidikan adalah lembaga yang dapat menawarkan reputasi, prospek, mutu pendidikan yang baik, prospek dan peluang yang cerah bagi para peserta didik.

Harga menurut Lupiyoadi dan Hamdani (2006:98) merupakan kegiatan Penentuan harga memainkan peranan penting, karena penentuan harga terkait langsung dengan pendapatan yang diterima oleh perusahaan. Sedangkan jika tarif jasa ditarik dalam dunia pendidikan, seperti yang diungkapkan oleh Faisal (Adam,2015:90) tarif jasa pendidikan merupakan sejumlah uang yang harus dibayar oleh para peminta jasa pendidikan dengan kata lain tarif atas tawaran yang dibeli oleh pasar sasaran. Penentuan harga bukan serta merta ditentukan semaunya oleh pihak organisasi yang berwenang.

Dalam jasa pendidikan harga atau tarif yang dibutuhkan, menurut Wijaya dalam 
skripsi Hidayatullah (2015:16) sebagai berikut:pertama, biaya satuan pendidikan operasi lancar yaitu biaya input pendidikan yang habis digunaan selama satu tahun atau kurang dan biaya yang dikeluarkan berulangulang per siswa per tahun. Kedua, biaya satuan pendidikan investasi modal pembangunan, yaitu biaya input pendidikan yang penggunaannya lebih dari satu tahun dan di hitung per siswa per tahun. Pendapat tokoh di atas dapat disimpulkan bahwa harga dalam konteks pendidikan merupakan seluruh biaya yang dikeluarkan untuk mendapatkan jasa pendidikan yang di tawarkan oleh sebuah sekolah. Dalam elemen harga dipertimbangkan mengenai penetapan harga (seperti pembayaran SPP, pembangunan gedung, biaya laboratorium), pemberian beasiswa, prosedur pembayaran.

Lokasi menurut Phillip Kotler dan Amstrong (Hidayatullah, 2015:18) ialah "place is a set of independent organization that help make a product or service available for use or consumption by the cnsomer or business user". Definisi lokasi tersebut diartikan sebagai kumpulan dari organisasiorganisasi yang bebas yang membuat suatu barang atau jasa menjadi tersedia, sehingga pelanggan dapat menggunakan atau mengkonsumsi barang atau jasa tersebut.

Alma dan Hurriyati (2008:160) membagi tiga macam tipe interaksi antara penyedia jasa dan pelanggan yang berhubungan dengan pemilihan lokasi antara lain:

a) Pelanggan mendatangi penyedia jasa. Pada tipe ini, lokasi menjadi sangat penting. Di dalam interaksi ini penyedia jasa yang menginginkan pertumbuhan dapat mempertimbangkan menawarkan jasa di beberapa lokasi untuk mempermudah pelanggan.

b) Penyedia jasa mendatangi pelanggan. Pada tipe ini dapat dikatakan lokasi tidak terlalu penting meskipun perlu dipertimbangkan pula kedekatan terhadap pelanggan untuk menjaga kualitas jasa yang akan diterima. Tipe ini mengharuskan kuantitas dari tenaga pemasar yang banyak untuk menjangkau seluruh sasaran dari organisasi.

c) Penyedia dan pelanggan melakukan interaksi melalui perantara. Letak lokasi dapat diabaikan dalam tipe ini meskipun beberapa media perantara memerlukan interaksi fisik antara penyedia jasa dengan pelanggan.

Berdasarkan ketiga tipe di atas, dapat disimpulkan dalam jasa pendidikan yakni pelanggan yang mendatangi penyedia jasa. Sehingg perlu lokasi yang mudah dijangkau untuk seluruh siswa. Menurut Alma dan Hurriyati (2008:161) dalam pemilihan tempat atau lokasi memerlukan pertimbangan yang cermat terhadap beberapa faktor sebagai berikut:

a. Akses, misal lokasi yang mudah djangkau oleh sarana transportasi

b. Visibilitas, lokasi yang mudah dilihat dengan jelas dari tepi jalan

c. Lalu lintas, dimana ada dua hal yang perlu dipertimbangkan yakni: banyaknya orang yang lalu lalang dapat memberikan peluang besar terjadinya kepadatan, dan kemacetan lalu lintas dapat pula menjadi hambatan

d. Tempat parkir yang luas, dengan adanya tempat parkir yang luas akan menjadikan pelanggan merasa nyaman meninggalkan kendaraan yan dimiliki.

e. Ekspansi, tersedia tempat yang cukup untuk perluasan usaha di kemudian hari

f. Lingkungan, lingkungan ataupun situasi di lingkungan lembaga yang tentram juga mampu manarik pelanggan untuk bergabung dengan lembaga.

g. Persaingan, yaitu lokasi pesaing yang berada di sekitar tempat/lokasi.

Penentuan lokasi sekolah akan mempengaruhi preferensi calon peserta didik 
dalam menentukan pilihannya. Lokasi sekolah perlu mempertimbangan lingkungan dimana lokasi itu berada (dekat dengan pusat kota atau perumahan, kondisi lahan parkir, lingkungan belajar yang kondusif) dan trasnportasi. Lokasi yang strategis dan mudah dicapai kendaraan umum akan menjadi daya tarik bagi calon peserta didik.

Sedangkan bukti fisik menurut Mulyasa (2009:49) bahwa sarana dan prasarana pendidikan adalah peralatan dan perlengkapan yang secara langsung dipergunakan untuk menunjang proses pendidikan, khusunya proses pembelajaran. Lovelock (Alma dan Hurriyati, 2008:166) menambahkan bahwa perusahaan melalui tenaga pemasarnya menggunakan tiga cara dalam mengelola bukti fisik yang strategis, antara lain:

a. an attention-creating medium. Perusahaan jasa melakukan differensiasi dengan pesaing dan membuat sarana fisik semenarik mungkin untuk menjaring pelanggan

b. an message-creating medium. Menggunakan simbol atau isyarat untuk mengkomunikasikan secara intensif kepada audiens mengenai kekhususan kualitas dari produk jasa

c. an effect-creating medium. Baju seragam yang berwarna, bercorak. Suara dan desain untuk menciptakan sesuatu yang lain dari produk jasa yang ditawarkan.

Berdasarkan pernyataan di atas, dapat disimpulkan bahwa sarana fisik dalam jasa pendidikan merupakan suatu lingkungan dimana sekolah dan siswa dapat berinteraksi dan di dalamnya terdapat komponenkomponen tangible yang mendukung kinerja dari jasa tersebut. Proses penyampaian jasa pendidikan kepada peserta didik, lembaga harus memperhatikan gaya bangunan serta fasilitas penunjang lainnya agar mampu menunjang pencapaian belajar peserta didik

Keputusan memilih merupakan kebutuhan yang setiap orang pasti mengalami termasuk keputusan untuk memilih sebuah lembaga pendidikan. Banyak faktor yang mempengaruhi keputusan seseorang menurut Kotler dan Amstrong antara lain: faktor kebudayaan, faktor psikologis, faktor sosial, dan faktor pribadi (Hurriyati,2005:94)

Berdasarkan penjabaran di atas, penulis tertarik untuk melakukan penelitian dengan judul "pengaruh strategi bauran pemasaran terhadap keputusan siswa dalam memilih MAN Tuban". Adapun rumusan masalah dari penelitian yakni apakah produk, harga, lokasi, dan bukti fisik secara individu berpengaruh terhadap keputusan siswa dalam memilih MAN Tuban, dan apakah produk, harga, lokasi, dan bukti fisik secara bersama-sama berpegaruh terhadap keputusan siswa dalam memilih MAN Tuban.

\section{METODE}

Penelitian ini menggunakan pendekatan kuantitatif dengan jenis penelitian korelasional. Menggunakan penelitian kuantitatif karena data yang akan dianalisis adalah angka dan berbentuk statistik serta akan menguji hipotesis statistik yang telah ditentukan sebelumnya, serta akan menganalisis hasil data dengan dengan rumus statistik. Penelitian ini terdiri dari 4 variabel bebas (X) yakni produk (X1), harga (X2), lokasi (X3), dan bukti fisik (X4) sedangkan variabel terikat keputusan memilih (Y). Berdasarkan variabel-variabel tersebut rancangan penelitian dalam penelitian ini sebagai berikut:

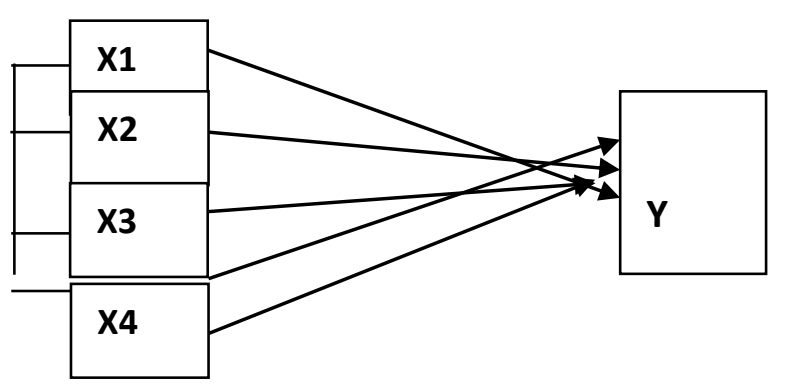

Gambar 1. Rancangan Penelitian 
Populasi dalam penelitian ini adalah siswa MAN Tuban kelas $\mathrm{X}$ yang terdiri dari 4 jurusan dan keseluruhan berjumlah 11 kelas. Jumlah keseluruhan populasi 432 siswa. dari jumlah populasi tersebut diambil sampel yang akan mewakili responden. Teknik pengambilan sampel dalam penelitian ini menggunakan teknik proporsional random sampling Adapun jumlah sampel dihitung dengan rumus $\mathrm{Al}$ Rasyid.

$$
\begin{aligned}
\text { no } \quad & =\left[\frac{Z a}{2 \cdot B E}\right]^{2} \\
& =\left[\frac{1,99}{2 \cdot(0,10)}\right]^{2} \\
& =(9,95)^{2} \\
& =99,0025 \\
& n o=0,05 \mathrm{~N}=0,05 \mathrm{x} 427=21,35
\end{aligned}
$$

karena no $>0,05$ atau 99,0025 > 21,35. maka besarnya sampel dapat dihitung dengan rumus:

$$
\begin{aligned}
\mathrm{n} & =\frac{n o}{1+\frac{n o-1}{n}} \\
& =\frac{99,0025}{1+\frac{99,0025-1}{427}} \\
& =\frac{99,0025}{1,229} \\
& =80,5=81
\end{aligned}
$$

Berdasarkan perhitungan di atas dapat ditarik kesimpulan bahwa jumlah sampel dalam penelitian berjumlah 81 siswa karena dibulatkan angka di atasnya. Dari jumlah sampel tersebut kemudian di tentukan jumlah masing-masing sampel menurut jurusan secara proporsional dengan rumus:

$$
\mathrm{ni}=\mathrm{Ni} / \mathrm{N} . \mathrm{n}
$$

$\mathrm{ni}=$ jumlah sampel menurut stratum

$\mathrm{n}=$ jumlah sampel seluruhnya

$\mathrm{Ni}=$ jumlah populasi menurut stratum

$\mathrm{N}=$ jumlah populasi seluruhnya

Dengan rumus di atas, maka diperoleh jumlah sampel masing-masing jurusan sebagai berikut:

$$
\begin{aligned}
& \text { IPA }=\frac{197}{427} \times 81=37,3 \\
& \text { IPS }=\frac{155}{427} \times 81=29,4 \\
& \text { Bahasa }=\frac{38}{427} \times 81=7,2 \\
& \text { Agama }=\frac{37}{427} \times 81=7,01
\end{aligned}
$$

\begin{tabular}{|c|c|c|c|}
\hline $\begin{array}{l}\text { variab } \\
\text { el }\end{array}$ & $\begin{array}{l}\text { Sub } \\
\text { variabel }\end{array}$ & indikator & item \\
\hline & & Produk inti & 1 \\
\hline & Produk $(X 1)$ & Produk formal & $2,3,4,5$ \\
\hline & & $\begin{array}{l}\text { Produk yang } \\
\text { disempurnakan }\end{array}$ & $\begin{array}{l}9,10,1 \\
1,12,1 \\
3\end{array}$ \\
\hline $\begin{array}{l}\text { variab } \\
\text { el }\end{array}$ & $\begin{array}{l}\text { Sub } \\
\text { variabel }\end{array}$ & indikator & item \\
\hline \multirow{11}{*}{$\begin{array}{l}\text { Bauran } \\
\text { Pemas } \\
\text { aran }\end{array}$} & \multirow[t]{2}{*}{ Harga (X2) } & $\begin{array}{l}\text { Produk yang } \\
\text { disempurnakan }\end{array}$ & $\begin{array}{l}9,10,1 \\
1,12,1 \\
3\end{array}$ \\
\hline & & $\begin{array}{l}\text { Biaya investasi } \\
\text { modal } \\
\text { pembangunan }\end{array}$ & $\begin{array}{l}14,15, \\
16,117\end{array}$ \\
\hline & \multirow[t]{3}{*}{ Lokasi (X3) } & Akses & $\begin{array}{l}18,19, \\
20\end{array}$ \\
\hline & & Lalu lintas & 21 \\
\hline & & Tempat parkir & 22,23 \\
\hline & \multirow{6}{*}{$\begin{array}{l}\text { Bukti fisik( } \\
\text { X4) }\end{array}$} & Ekspansi & 24 \\
\hline & & lingkungan & 25,26 \\
\hline & & Kompetisi & 27,28 \\
\hline & & $\begin{array}{l}\text { An attention- } \\
\text { creating medium }\end{array}$ & $\begin{array}{l}29,30, \\
31,32, \\
33,34\end{array}$ \\
\hline & & $\begin{array}{l}\text { as a message- } \\
\text { creating medium }\end{array}$ & 35 \\
\hline & & An effect- & 36,37 \\
\hline
\end{tabular}

Berdasar perhitungan di atas dapat disimpulkan bahwa jumlah sampel yang diambil untuk jurusan IPA 37 siswa, IPS 30 siswa, Bahasa 7 siswa, dan agama 7 siswa, jadi total sampel 81 siswa.

Pengumpulan data pada penelitian ini menggunakan angket atau kuesioner dengan emppat pilihan jawaban yakni sangat setuju (SS), setuju (S), tidak setuju (ST), dan sangat tidak setuju (STS). Adapun kisi-kisi instrumen penelitian dapat dilihat pada tabel di bawah ini:

Tabel 1. Kisi-kisi Instrumen Penelitian 


\begin{tabular}{|c|c|c|c|}
\hline & & $\begin{array}{l}\text { Creating } \\
\text { medium }\end{array}$ & 38 \\
\hline \multirow{14}{*}{$\begin{array}{l}\text { Keput } \\
\text { usan } \\
\text { memili } \\
\text { h }\end{array}$} & \multirow{3}{*}{$\begin{array}{l}\text { Faktor } \\
\text { Kebudayaan }\end{array}$} & budaya & 39,40 \\
\hline & & Sub budaya & 41,42 \\
\hline & & Kelas sosial & 43,44 \\
\hline & \multirow{3}{*}{ Faktor sosial } & Kelompok & 45 \\
\hline & & Keluarga & $\begin{array}{l}46,47, \\
48,49\end{array}$ \\
\hline & & Peran dan status & 50 \\
\hline & \multirow{4}{*}{$\begin{array}{l}\text { Faktor } \\
\text { pribadi }\end{array}$} & Umur & 51 \\
\hline & & Pekerjaan & 52,53 \\
\hline & & Gaya hidup & 54 \\
\hline & & kepribadian & 55 \\
\hline & \multirow{4}{*}{$\begin{array}{l}\text { Faktor } \\
\text { psikologis }\end{array}$} & Motivasi & 56,57 \\
\hline & & Persepsi & 58 \\
\hline & & pengetahuan & 59 \\
\hline & & $\begin{array}{l}\text { Keyakinan\&sika } \\
\text { p }\end{array}$ & $\begin{array}{l}60,61, \\
62\end{array}$ \\
\hline
\end{tabular}

Teknik analisis data dalam penelitian ini menggunakan uji T dan uji F. Uji T digunakan untuk mengetahui pengaruh masing-masing variabel, sedangkan uji $\mathrm{F}$ digunakan untuk mengetahui pengaruh secara bersama-sama. Sebelum data hasil penelitian dihitung, terlebih dahulu dilakukan uji persyaratan analisis data yakni uji normalitas dan uji linearitas.

uji normalitas data menggunakan uji Kolmogrov Sminov pada program SPSS 21.0 untuk mengetahui asumsi kenormalan data. Data dikatakan normal apabila memiliki besarnya Phitung > 0,05, maka dikatakan berdistribusi normal, dan sebaliknya jika Phitung $<0,05$ maka data tidak berdistribusi normal. Pengujian linearitas dalam penelitian ini menggunakan program SPSS dan analisis yang digunakan adalah teknik one way anova. One way anova merupakan teknik statistik yang digunakan untuk menguji komparatif data yang saling berkorelasi dengan jenis data interval.

\section{HASIL DAN PEMBAHASAN}

Hasil penelitian menunjukan pada variabel produk (X1) responden menjawab setuju sebesar $72 \%$ dan tidak setuju sebesar 9,5\%. Pada variabel harga (X2) responden menjawab setuju sebesar $83 \%$ dan tidak setuju sebesar $16,88 \%$. Variabel lokasi (X3) responden menjawab setuju sebesar $83,99 \%$ dan tidak setuju sebesar $16 \%$. Variabel bukti fisik (X4) responden menjawab setuju sebesar $88,3 \%$ dan tidak setuju sebesar $11,7 \%$. Dan untuk variabl Y responden menjawab setuju sebesar 76,88\% dan tidak setuju sebesar 21\%. Dari hasil tersebut kemudian dilakukan perhitungan untuk membuktikan ada tidaknya pengaruh variabel bebasa terhadap veariabel bebas.

Sebelum perhitungan uji $\mathrm{T}$ dan uji $\mathrm{F}$, perhitungan uji persyaratan analisis data. data pada penelitian ini memenuhi uji normalitas adapun hasil nilai perhitungan uji normalitas yaknivariabel produk $0,237 \geq 0,05$, variabel harga $0,133 \geq 0,05$, variabel lokasi 0,106 $\geq 0,05$, variabel sarana fisik $0,110 \geq 0,05$, dan variabel keputusan sebesar 0,267 $\geq 0,05$. Berdasarkan perhitungan tersebut dapat disimpulkan bahwa seluruh variabel memenuhi uji normalitas karena nilai asymp.sig (2 tailed) $\geq 0,05$. Sedangkan pada uji linearitas juga terpenuhi karena seluruh variabel nilai sig > 0,05 .

Hasil perhitungan uji $\mathrm{T}$ diperoleh nilai $\mathrm{T}_{\text {hitung }}$ masing-masing variabel sebagai berikut: produk 0,372, lokasi 3,643, dan bukti fisik 2,690 . Nilai variabel produk dan harga < nilai $\mathrm{T}_{\text {tabel }}(1,99)$ sehingga diperoleh hipotesis $\mathrm{H} 0$ diterima dan $\mathrm{H} 1$ ditolak yang artinya produk tidak mempunyai pengarub terhadap keputusan siswa memilih MAN, dan harga juga tidak berpengaruh terhadap keputusan memilih MAN Tuban. Untuk variabel lokasi dan bukti fsik karena nilai $\mathrm{T}_{\text {hitung }}>$ nilai $\mathrm{T}_{\text {tabel }}$ maka $\mathrm{HO}$ ditolak dan $\mathrm{H} 1$ diterima yang artinya lokasi dan bukti fisik berpengaruh terhadap keputusan siswa dalam memilih MAN Tuban. Sedangkan pada perhitungn uji $\mathrm{F}$ memperoleh nilai $\mathrm{F}_{\text {hitung }}>$ 
$F_{\text {tabel }}$ yakni sebesar 17,941 $>2,46$. Dan nilai signifikan sebesar $0,000<0,05$ sehingga $\mathrm{H} 0$ ditolak dan $\mathrm{H} 1$ diterima artinya secara bersama-sama produk, harga, lokasi, dan bukti fisik memberikan pengaruh terhadap keputusan siswa memilih MAN Tuban. Adapun besarnya pengaruh dapat dilihat dari nilai koefisien determinasi sebesar 0,486 atau $48 \%$.

Berdasarkan perhitungan di atas, maka hasil penelitian tentang pengaruh produk terhadap keputusan siswa tidak sejalan dengan pendapat Irianto (2015:201) yang menyatakan bahwa produk merupakan hal yang paling mendasar menjadi pertimbangan referensi pilihan bagi masyarakat. Teori tersebut menjelaskan bahwa sebelum adanya keputusan, produk menjadi pertimbangan dalam mengambil keputusan. Produk dalam pendidikan yang merupakan bidang jasa khususnya pada lingkup sekolah merupakan jurusan yang dimiliki lembaga, ekstrakurikuler, mata pelajaran, pelayanan, dan segala aktivitas yang diberikan sekolah kepada siswa. Jurusan yang dimiliki MAN Tuban terdiri dari 4 jurusan yakni IPA, IPS, Bahasa, dan Agama. Jurusan-jurusan tersebut tentu bukanlah jurusan yang asing di kalangan sekolah menengah atas. Mayoritas sekolah menengah atas di Tuban, baik sekolah keagamaan maupun sekolah umum mempunyai jurusan semacam itu, sehingga dapat dikatakan bahwa tidak berpengaruhnya produk MAN Tuban terhadap keputusan siswa karena banyaknya pilihan bagi siswa memilih sekolah lain yang tentunya lebih baik dari MAN Tuban untuk menempuh jurusan yang di inginkan.

Produk dalam bidang jasa merupakan hal yang bersifat intangible yakni tidak nyata dalam artian jurusan dan ektrakurikuler yang dimiliki oleh lembaga pendidikan tidak mampu mempengaruhi calon siswa untuk secara langsung menilai baik buruknya produk yang dimiliki lembaga. Kebanyakan masyarakat mengetahui mengenai jurusan dan ektrakurikuler lembaga melalui mulut ke mulut saja, tanpa mampu melihat dan merasakan secara real, sehingga menjadikan calon siswa tidak yakin terhadap produk lembaga. selain faktor tersebut, dari pihak siswa sendiri bisa saja lebih mudah memahami item pertanyaan berupa hal yang nyata seperti lokasi dan bukti fisik dari pada hal yang tidak nyata seperti jurusan.

Hasil penelitian ini sama dengan jurnal penelitian yang dilakukan oleh Putra (2012:147) yang menghasilkan produk tidak berpengaruh terhadap penjualan kartu perdana XL di kota Padang. Selain itu, hasil penelitian ini juga sama dengan penelitian yang dilakukan oleh Hidayatullah (2015:92) yang menghasilkan produk tidak berpengatuh terhadap keputusan siswa memilih SMA yayasan pendidikan islam darussalam Cimanggis-Ciputat. Hasil penelitian menunjukan bahwa diantara unsur-unsur bauran pemasaran hanya unsur bukti fisik yang mempengaruhi siswa memilih SMA yayasan pendidikan islam darussalam CimanggisCiputat. Dari kedua penelitian tersebut dapat dikatakan tidak semua produk yang dimiliki lembaga menjadi prioritas utama untuk memilih sebuah lembaga pendidikan.

Penelitian mengenai pengaruh variabel harga terhadap keputusan siswa memilih MAN Tuban ini menunjukan persamaan dengan hasil penelitian Hidayatullah (2015:92) yang menghasilkan harga tidak berpengaruh terhadap keputusan siswa memilih SMA yayasan pendidikan islam darussalam Cimanggis-Ciputat. Hasil penelitian menunjukan bahwa diantara unsur-unsur bauran pemasaran hanya unsur bukti fisik yang mempengaruhi siswa memilih SMA yayasan pendidikan islam darussalam CimanggisCiputat. Selain itu, hasil penelitian ini juga sama dengan hasil penelitian Wangsa (2012:10) yang menghasilkan harga tidak mempengaruhi keputusan konsumen dalam membeli produk sebuah perusahaan. Hasil penelitian serupa juga dilakukan oleh Putra (2012:197) bahwa unsur produk, harga, dan promosi tidak berpengaruh terhadap keputusan pelanggan membeli kartu prabayar XL di Kota Padang

Melihat fenomena saat ini, dimana orang tua yang menginginkan anaknya mendapatkan 
pendidikan sebaik mungkin tidak memperdulikan besarnya biaya yang ditarifkan oleh sekolah, karena orangtua yang paham akan pendidikan akan menyadari bahwa pendidikan bermutu diperlukan biaya yang tidak sedikit. Harga dalam bidang pendidikan merupakan tarif yang harus dikeluarkan oleh siswa untuk operasional penyelenggaraan pendidikan sehari-hari. Pada tataran SMA pada umumnya anak-anak masih menjadi tanggungjawab orangtua siswa, sehingga kemungkinan tidak berpengaruhnya harga terhadap keputusan siswa memilih MAN Tuban karena siswa tidak memperdulikan terhadap biaya yang ditarifkan MAN Tuban karena hal tersebut merupakan tanggungjawab orangtua para siswa. selain itu, berdasarkan informasi yang diperoleh dari pihak MAN Tuban diketahui bahwa sebagian besar siswa MAN Tuban berasal dari golongan menengah ke atas karena sebagian besar para siswa berasal dari daerah pesisir seperti daerah perbatasan tuban-lamongan yang kebanyakan berprofesi sebagai nelayan, sehingga SPP sebesar Rp.50.000 bagi orangtua siswa MAN Tuban tidak berpengaruh terhadap keputusan memilih MAN Tuban.

Pada hasil penelitian variabel lokasi sejalan dengan hasil penelitian yang dilakukan oleh Zuardi (2012:11) yang menghasilkan diantara unsur produk, harga, promosi, orang, proses, dan pelayanan pelanggan hanya unsur lokasi/tempat yang berpengaruh terhadap keputusan memilih jurusan Manajemen STIE Muhammadiyah Asahan. Selain itu, penelitian mengenai variabel lokasi terhadap keputusan siswa memilih MAN Tuban ini telah membuktikan teori dari Bennet (Adam,2015:92) mengatakan bahwa lokasi pelayanan yang akan digunakan dalam memberikan pelayanan kepada pelanggan merupakan kunci dari kegiatan pemasaran, karena itu keputusan mengenai tempat atau lokasi pelayanan yang akan digunakan memerlukan kajian yang dalam dan matang, agar tempat dan lokasi pelayanan dalam pemberian jasa memberikan kenyamanan dan kepuasan sehingga dapat mendorong nilai tambah yang tinggi bagi pelanggan, karenanya lokasi atau tempat pelayanan yang akan ditetapkan harus memberikan nilai strategis baik dari pesrspektif lingkungan dan kenyamanan.

Ketepatan lokasi sekolah terhadap pengambilan keputusan siswa dalam memilih MAN Tuban mencerminkan bahwa siswa mempertimbangkan nilai ekonomis, geografis, service, serta pedagogis. Dengan pertimbangan hal-hal tersebut diharapkan mampu mendukung keberhasilan belajar para siswa. Berdasarkan beberapa penjelasan di atas, dapat disimpulkan bahwa terdapat keselarasan antara teori yang ada dengan hasil penelitian yang telah dilakukan. Pengaruh variabel lokasi memberikan kontribusi yang meliputi akses yang mudah, lalu lintas yang lancar, tempat parkir, ekspansi, dan kompetisi terhadap keputusan siswa dalam memilih MAN Tuban.

Hasil peneltian pada variabel bukti fisik terhadap keputusan siswa dalam memilih MAN Tuban membuktikan teori Adam (2015:39) yang menyatakan sarana fisik atau bukti fisik merupakan suatu hal yang secara nyata turut mempengaruhi keputusan konsumen, untuk membeli dan menggunakan produk jasa yang ditawarkan. Hasil penelitian ini juga mendukung teori Mulyasa (2009:49) bahwa sarana dan prasarana pendidikan adalah peralatan dan perlengkapan yang secara langsung dipergunakan untuk menunjang proses pendidikan, khusunya proses pembelajaran.

Bukti fisik yang dimililiki MAN Tuban mampu mempengaruhi keputusan siswa memilih MAN Tuban karena MAN Tuban menerapkan langkah strategis seperti pendapat yang diungkapkan oleh Lovelock (Alma dan Hurriyati,2008:166) bahwa terdapat tiga cara strategis antara lain: An attention-creating medium, As a Message-creating medium, dan An effect verating-medium. Adapun penerapan ketiga cara tersebut di MAN Tuban antara lain: pertama, bangunan luar MAN Tuban terlihat rapi dengan adanya banyak pepohonan yang rindang di depan bangunan MAN Tuban, selain itu penataan gedung yang ditata dengan rapi 
memudahkan siswa untuk melakukan aktivitas. Kedua, di depan bangunan MAN Tuban tertulis visi dan misi MAN Tuban yang dapat dilihat secara langsung oleh masyarakat luar. Dan ketiga, seragam MAN Tuban yang menarik dengan motif dan desain yang berbeda dengan sekolah menengah atas lainnya.

Secara terpisah produk, harga, lokasi, dan bukti fisik hanya lokasi dan bukti fisik yang berpengauh, akan tetapi secara bersama-sama produk, harga, lokasi, dan bukti fisik berdasarkan hasil perhitungan mampu mempengaruhi keputusan siswa memilih MAN Tuban. Produk, harga, lokasi, dan bukti fisik yang dikelola oleh MAN Tuban dengan baik mampu menarik calon pelanggan untuk memilih lembaga MAN Tuban. Pengelolaan variabel-variabel tersebut tentu saja memerlukan sebuah sinergi beberapa pihak untuk mendapatkan hasil optimal, sehingga produk, harga, lokasi, dan bukti fisik menjadi alasan kuat bagi siswa memilih MAN Tuban. Setalah usaha untuk meningkatkan variabelvariabel tersebut, siswa akan melihat dan menilai sendiri keunggulan dari variabel tersebut. Pendapat tersebut senada dengan pendapat Muhaimin, dkk (2009:117) yang menyatakan bahwa setelah menerima/mengetahui dari pemasaran yang dilakukan oleh pihak pemasar diharapkan masyarakat dapat mengambil keputusan. Pengambilan keputusan ini akan lebih berhasil setelah melalui tahapan "dialog diri". Dialog diri merupakan kesatuan proses dalam diri individu untuk memutuskan meilih ataupun tidak.

Pemilihan produk yang tepat akan menjadikan siswa mengenyam pendidikan dengan jurusan yang memang diminati, ekstrakurikuler yang mampu menunjang bakat siswa, dan mendapatkan mata pelajaran yang dibutuhkan untuk masa depan. Dengan pertimbangan harga yang tepat akan menjadikan siswa nyaman bersekolah di lembaga yang dipilih, karena tarif yang di sepakati tidak akan membebani orang tua siswa. Dengan pertimbangan lokasi yang matang akan memudahkan siswa dalam melakukan perpindahan ke sekolah, dan dengan pertimbangan sarana fisik yang benar akan menjadikan peningkatan kemampuan dan pengetahuan siswa menjadi optimal, karena ditunjang oleh sarana dan prasarana yang memadai.

\section{PENUTUP}

\section{Simpulan}

Berdasarkan hasil perhitungan mengenai baurau pemasaran pengaruhnya terhadap keputusan siswa dapat disimpulkan bahwa a) produk tidak berpengaruh terhadap keputusan siswa memilih MAN Tuban, b) harga tidak berpengaruh terhadap keputusan siswa memilih MAN Tuban, c) lokasi berpengaruh terhadap keputusan siswa memilih MAN Tuban, d) bukti fisik berpengaruh terhadap keputusan siswa memilih MAN Tuban, dan e) secara bersama-sama produk, harga, lokasi, dan bukti fisik berpengaruh terhadap keputusan siswa memilih MAN Tuban.

\section{Saran}

Berdasarkan hasil penelitian dan kesimpulan yang telah dipaparkan di atas, penulis menawarkan beberapa saran kepada pihak yang terkait, antara lain:

1. Bagi kepala sekolah

a. Kepala sekolah beserta jajaran petinggi MAN Tuban agar mampu mengembangkan dan meningkatkan animo masyarakat untuk mmemilih MAN Tuban. Hal yang bisa dilakukan yakni dengan menyusun inovasi dalam produk dan harga di MAN Tuban. Inovasi tersebut bisa berupa penambahan ekstakurikuler, mata pelajaran, jurusan, ataupun kegiatan lain yang menunjukan keunggulan dan kekhasan MAN Tuban.

b. Pada variabel lokasi dan bukti fisik yang terbukti mampu memberikan pengaruh terhadap keputusan siswa memilih MAN Tuban, hendaknya kepala sekolah lebih memperlengkap sarana fisik MAN Tuban, dengan sarana/bukti fisik yang memadai dan tertata dengan rapi akan memudahkan manarik minat siswa untuk memilih lembaga.

c. Kepala sekolah agar menggerakkan para guru dan staf untuk bersama-sama membangun MAN Tuban dengan segala kekuatan yang dimiliki MAN Tuban untuk menjadi sekolah tingkat menengah atas 
yang menjadi pilihan utama bagi siswa Tuban.

2. Bagi wakil kepala sekolah bagian hubungan Masyarakat

Hasil penelitian menunjukan lokasi dan bukti fisik memberikan pengaruh terhadap keputusan siswa memilih MAN Tuban. Dua variabel tersebut yakni lokasi dan bukti fisik bisa dipergunakan oleh wakil kepala sekolah bagian hubungan masyarakat untuk memasarkan MAN Tuban dengan jangkauan pemasaran yang lebih luas, sehingga MAN Tuban bisa dikenal dan menjadi pilihan bagi siswa-siswa yang jauh dari kota Tuban maupun dari luar kota Tuban.

3. Bagi peneliti lain

Bagi peneliti yang akan melakukan penelitian dengan topik yang sama dengan penelitian ini, hendaknya menggunakan aspek dan metode yang berbeda agar bisa melengkapi hasil penelitian ini dan pembahasan menjadi lebih mendalam.

\section{DAFTAR PUSTAKA}

Adam, Muhammad. 2015. Manajemen Pemasaran Jasa. Bandung: Alfabeta

Alma. bukhori dan Ratih Hurriyati. 2008. Manajemen Corporate Dan Strategi Pemasaran Jasa Pendidikan Fokus Pada Mutu Dan Pelayanan Prima. Bandung:Alfabeta

Hidayatullah, Muhammad Syarif. 2015. Analisis strategi Bauran Pemasaran Terhadap Keputusan Konsumen Memilih Sekolah Menengah Atas (SMA) Yayasan Pendidikan Islam Darussalam Cimanggis-Ciputat. Skripsi. (online). Tersedia pada Http://respositori.uinsyarifhidayatullah.a c.id diakses pada 15 November 2015 pukul 13.00 WIB

\footnotetext{
Hurriyati, Ratih. 2005. Bauran Pemasaran Dan Loyalitas Konsumen. Bandung:Alfabeta
}

Irianto,Yoyon Bahtiar. 2015. Pemasaran Pendidikan. E-book. Bandung:Universitas Pendidikan Indonesia (online) pada Http://file.upi.edu.ac.id diakses pada 12 Januari 2016 pukul 18:00 WIB.

Kotler, Phillip. 1984. Marketing Management: Analisis, Perencanaan, dan Pengendalian, Edisi ke-Empat jilid 2: alih bahasa oleh Ellen Gunawan. USA: Erlangga

Lupiyoadi, Rambat dan A.Hamdani. 2006. Manajemen Pemasaran Jasa, Edisi 2. Jakarta:Salemba Empat.

Machali. Imam. 2012. Marketing Mix Untuk Meningkatkan Mutu di SD MUHAMMADIYAH Sapen. Karya tulis (online) pada http://academia.edu.ac.id diakses 23 November 2015 pukul 13:00 WIB

Muhaimin, dkk. 2009. Manajemen Pendidikan Aplikasinya dalam Penyusunan Rencana Pengembangan Sekolah/Madrasah. Jakarta:Kencana Perdana Media group.

Mulyasa, E. 2004. Manajemen Berbasis Sekolah .Bandung: PT. Remaja Rosda Karya

Putra Hafrizah Okta Ade Putra. 2013. Pengaruh Bauran Pemasaran Jasa Terhadap Keputusan Pembelian Kartu Perdana Prabayar XL di kota Padang. Jurnal Manajemen dan Kewirausahaan, Vol 3, Januari 2013 ISSN:2086-5031

Wangsa, Arief Muhammad. 2012. Analisis Marketing Mix terhadap Keputusan Pembelian Pakan Ternak Japfa di Sulawesi Selatan (Studi Kasus di PT.JAFRA COMFEED Indonesia, Tbk Unit Makassar. Makassar.

Wijaya, David. 2008. Pemasaran Jasa Pendidikan sebagai Upaya Untuk 
78 Jurnal Dinamika Manajemen Pendidikan Vol. 1 No. 1 Tahun 2016 Hal. 68-78

Meningkatkan Daya Saing Sekolah; jurnal pendidikan Penabur Nomor 11/Tahun ke-7.Jakarta: BPK Penabur (online) pada www.bpkpenabur.or.id diakses 13 November 2015 pukul 13.00.

Zuardi, Muhammad. 2012. Pengaruh Strategi Bauran pemasaran Yang Mempengaruhi Keputusan Mahasiswa Memilih Jurusan Manajemen STIE Muhammadiyah Asahan. Medan: Politeknik Negeri Medan 